\title{
Artigos
}

Persp. Teol. 34 (2002) 11-36

\section{ROMPER O MAL-ESTAR NA MISSÃO OS POVOS INDÍGENAS E A IGREJA PÓS-CONCIIAR}

Paulo Suess

A história da relação entre povos indígenas e Igreja é marcada por uma sucessão de "desconfortos" que, em escala menor, continuam até hoje. A partir desta constatação se impõe a pergunta se esses desconfortos, no passado, eram evitáveis e hoje, olhando para o futuro, são corrigíveis.

O "mal-estar na civilização", segundo Freud, é expressão de uma ambivalência estrutural, proveniente de ideais de felicidade e prazer que nunca podem ser alcançados: "O programa de tornar-se feliz, que o princípio do prazer nos impõe, não pode ser realizado; contudo, não devemos - na verdade, não podemos - abandonar nossos esforços de aproximá-lo da consecução, de uma maneira ou de outra"1.

Pode a missão escapar deste desconforto cultural e civilizatório, embutido no cristianismo que quer, através do seu caminho de salvação, a felicidade de toda a humanidade, cuja realização está norteada pelo imperativo do "amor maior"? Como articular a totalidade quantitativa e qualitativa com o "amor maior"?

Este amor, antes de admitir a prática de violência contra os outros, oferece a própria face e a própria vida. Limitar o caminho da felicida-

${ }^{1}$ S. FREUD, "O mal-estar na civilização", in: Idem, Obras Completas, Vol. XXI (19271931), Rio de Janeiro: Imago, 1974, pp. 81-171, aqui 102. 
de ao próprio caminho sempre levará à exclusão ou ao impasse de forçar os outros à incorporação na própria felicidade ${ }^{2}$. A suposta autoexclusão e infelicidade da maior parte da humanidade, que não faz parte da felicidade padronizada pelo cristianismo, tampouco tranqüiliza as consciências cristãs. Qualquer atitude - de não ter feito o suficiente para a incorporação do outro ou de ter feito por meios de poder e violência - causa sentimentos de culpa. Assim o cristianismo se torna bode expiatório e causador de culpa por tudo: pelo excesso de zelo missionário, cujos vestígios se encontram na "guerra santa" e na "intolerância religiosa", e pelo relaxamento do zelo missionário, supostamente apontado pelos paradigmas da "evangelização implícita", do "diálogo inter-religioso" e na fórmula que considera todo ser humano um "cristão anônimo".

Por conseguinte, setores "zelosos" e "relaxados" são marcados por sentimentos de culpa e se acusam reciprocamente; uns, pela violência dos meios aplicados, outros, pela diluição e transferência de conteúdos para o campo social que supostamente os impede de pregar "todo o evangelho". Ambos os setores compensam seus sentimentos de culpa, muitas vezes, com discursos apologéticos e com "cara feia do sofredor pela causa" que apontam para a escassez de felicidade em sua vida, por falta ou por excesso de auto-estima.

Estas são algumas questões de fundo deste texto: a prática da missão sem culpa, sem sacrificialismo que está sempre na origem de uma violência, afinal, "viver e não ter vergonha de ser feliz". Também o tempo pós-conciliar não venceu ainda o mal-estar na missão. Ele é o "demônio" que nos procura atacar pelas costas. Vencê-lo-emos, não pela fuga, porque ele é mais rápido, nem pelo confronto, porque ele é mais forte, mas pelo diálogo e a razão da nossa esperança.

\section{O mal-estar}

Seis anos depois do Concílio Vaticano II, a declaração dos antropólogos que participaram, de 25 a 30 de janeiro de 1971, em Barbados, do "Simpósio sobre a fricção interétnica na América do Sul", causou um

${ }^{2}$ Esta era, geralmente, a opção da cristandade. Cf. a carta do Ir. J. de ANCHIETA ao P. D. LAYNEZ (16.4.1563), in: S. LEITE, Cartas dos primeiros Jesuítas do Brasil, t. III, São Paulo: Comissão do IV Centenário da Cidade de S. Paulo, 1954, p. 554: "Parécenos agora que están las puertas abiertas en esta Capitanía para la conversión de los gentiles, si Dios N. Señor quisiere dar manera con que sean subjectados y puestos debaixo de jugo, porque, para este género de gente, no ay major predicatión que espada y vara de hierro, en la qual más que en ninguna otra, es necessario que se cumpla el compelle eos intrare (Lc. 14,23)". 
mal-estar muito grande na comunidade missionária ${ }^{3}$. Segundo os antropólogos, "o conteúdo etnocêntrico da atividade evangelizadora" das missões religiosas está baseado:

- no "seu caráter essencialmente discriminatório originado em uma relação hostil com as culturas indígenas que classifica como pagãs e heréticas";

- na "sua natureza vicarial" e advocatória (paternalista);

- na sua potência econômica que fez as missões se converterem "em uma grande empresa de recolonização e dominação, em conivência com os interesses imperialistas dominantes".

Em virtude desta análise, os antropólogos propõem "acabar com toda atividade missionária" e exigem sua revisão radical. Os missionários devem:

- "superar o herodianismo intrínseco à atividade catequizadora como mecanismo de colonização, europeização e alienação das populações indígenas;

- respeitar as "culturas indígenas, pondo fim à longa e vergonhosa história de despotismo e intolerância";

- "acabar com a indiferença diante da constante espoliação de que os indígenas são objeto por parte de terceiros";

- "pôr um fim na disputa entre confissões e agências religiosas pelas almas dos indígenas" que "os divide e conduz a lutas internas";

- "suprimir as práticas seculares de ruptura da família indígena pelo internamento das crianças em orfanatos";

- "suspender imediatamente toda prática de deslocamento ou concentração de populações indígenas com fins de catequese ou assimilação".

Por fim, Barbados propõe medidas que hoje são amplamente respaldadas na prática pastoral:

- o protagonismo dos povos indígenas na definição de seu destino;

- a autodeterminação: "a libertação das populações indígenas ou é realizada por elas mesmas ou não é libertação";

- a organização indígena pan-americana e alianças com grupos oprimidos;

- a assunção da vida indígena como uma das muitas "vias alternativas aos caminhos já transitados pela sociedade nacional".

O Encontro Ecumênico de Assunção, em março de 1972, com representantes de nove países, respondeu à Declaração de Barbados I (1971)

${ }^{3} \mathrm{O}$ texto da Declaração do "Simpósio sobre a fricção interétnica na América do Sul", in: P. SUESS (org.). Em defesa dos povos indígenas. Documentos e legislação, São Paulo: Loyola, 1980, pp. 19-26. 
e à sua proposta de uma moratória para a atividade missionária ${ }^{4}$ O Documento Final do encontro reconhece que "nossas Igrejas, mais de uma vez, têm sido coniventes ou instrumentalizadas por ideologias e práticas opressoras do homem". Mas, segundo o documento, os erros históricos não anulam a razão de ser da Igreja, que tem a missão de "descobrir a presença de Deus Salvador em todo povo e cultura". Por fim, os missionários reunidos em Assunção se comprometem a abrir espaço para o diálogo e a participação dos próprios índios na pastoral missionária que deverá visar a uma "libertação integralmente humana e profundamente cristã".

De fato, não era difícil apontar missões cuja atuação, na época, confirmou as denúncias de Barbados. Ainda em 1978, o missionário e antropólogo Alcionílio Brüzzi Alves da Silva, por exemplo, insistiu no imperativo civilizatório da missão: "Em nossas freqüentes excursões de exploração e estudos desde 1947, temos - não sem emoção nossa -, verificado uma ânsia de civilizar-se por parte daqueles indígenas, ânsia que se traduzia, algumas vezes no pedido insistente que ficássemos entre eles" $^{\prime \prime}$. O missionário que passou, praticamente, toda a sua vida profissional nas missões do Rio Negro (AM), afirma sem hesitação:

"Praticamente as Tribos do Uaupés não apresentam religião alguma. E, conseqüentemente estão sob o peso asfixiante de crenças e práticas mágicas. Dispensa provas a vantagem de uma convivência longa (...) com pessoas de alta cultura e elevada religiosidade e moralidade, como os Missionários. E como são de lamentar-se os inconvenientes de contatos só com caboclos, semi-índios, semi-civilizados, marginais da civilização, da moralidade e da religião. (...) Quiçá melhor que o termo Catequese, se deva falar de um Processo Civilizador da Missão Salesiana do Rio Negro (MSRN)" ${ }^{6}$.

O objetivo e o efeito da passagem pela missão é assim descrito pelo missionário:

"E voltam entre os seus 'irmãos' com a mente mais esclarecida, um conforto material maior, uma crença no Deus Criador do céu e da terra, Senhor, Juiz e Pai, e uma esperança de uma velhice menos triste, alentada pelas esperanças de uma vida futura feliz e sem termo" 7 .

${ }^{4}$ O Simpósio de Barbados foi auspiciado pelo Programa de combate ao racismo do Conselho Mundial das Igrejas. Cf. o documento final do Encontro Ecumênico de Assunção e a Declaração do Simpósio sobre a fricção interétnica na América do Sul (Barbados I), in: P. SUESS (org.), Em defesa..., Op. cit., pp. 27-30 e 19-26.

${ }^{5}$ A. BRÜZZI ALVES DA SILVA, As tribos do Uaupés e a civilização brasileira: o método civilizador salesiano. O Índio tem o direito de ser índio ou de ser civilizado? Belém, 1978, p. 13.

${ }^{6}$ Ibidem, p. 14ss.

${ }^{7}$ A. BRÜZZI ALVES DA SILVA, A civilização indígenas do Uaupés, Roma: Libreria Ateneo Salesiano, 1977, $2^{\text {a }}$ ed., p. 426. 
E a respeito dos destinatários preferenciais desta missão, o missionário defende antigas práticas:

"Os maiores esforços devem ser dirigidos para a geração nova. Para esta a MSRN procurou criar no mais longínquo da selva amazônica um ambiente de civilização, onde, sem atritos, sem violência, o indígena vá assimilando, quase sem o perceber, uma civilização humana, cristã e brasileira. São os internatos, aos quais a criança, filha de pais indígenas, talvez se tenha apresentado mais nua na alma do que no corpo (...)" 8 .

A missão civilizadora é a missão das "melhores intenções". "Erraram? Pode ser... Mas amaram!", exclama o padre geral frei Leonardo Trotta, ao referir-se a seus confrades mártires de Alto Alegre, e, perguntado sobre a nota que ele daria aos seus confrades missionários do Maranhão, responde, com generosidade: "dez, com louvor" . A missão civilizatória é, além de ser autocomplacente e apologética, também dispendiosa. Obras pesadas fazem parte de seu processo evangelizador:

"Este processo exige despesas de milhões, que são subministrados, em parte, pelas Verbas oficiais e, em parte, pelas doações de instituições eclesiásticas ou particulares. Exige, porém, muito mais do que isto; exige (...) um espírito de sacrifício que muitas vezes, raia pelo heroísmo, sacrifício que só um intenso amor de Deus, o amor da Pátria e o senso da fraternidade humana podem suscitar e manter" 10 .

A missão civilizatória silencia o elemento profético da evangelização e tenta resolver os conflitos na negociação "em alto nível". Ela ganhou elogios dos governantes e reconhecimento das nunciaturas ${ }^{11}$. "O índio brasileiro, neste longínquo rincão de nossa pátria, não poderia ter melhor assistência"12, avalia, em 19 de maio de 1974, o então presidente da Funai, general Ismarth de Araújo Oliveira, a Missão do Rio Negro. Silenciando os povos indígenas e jogando a sua memória de paixão e ressurreição no rio do esquecimento, a missão civilizatória evita os conflitos e endossa as explicações oficiais nas quais assassinatos se tornam "acidentes" e conquistas, "encontros de culturas".

Esta prática missionária não foi a prerrogativa de um ou outro instituto missionário. Existiam, nas Américas da época, também outras

\footnotetext{
${ }^{8}$ A. BRÜZZI ALVES DA SILVA, As tribos do Uaupés..., Op. cit., pp. 17s.

${ }^{9}$ Cf. L. TROTTA, Saíram para semear... e já faz cem anos que a semente caiu em terra boa: Primeiro Centenário 1893-1993 da presença dos capuchinhos lombardos no norte e nordeste do Brasil, Gorle (Bérgamo - Itália):Velar, 1993, pp. 290-295. ${ }^{10}$ A. BRÜZZI ALVES DA SILVA, As tribos do Uaupés..., Op. cit., p. 24.

11. Cf. P. CALMON, De Tupan a Cristo: Jubileu de ouro, 1915-1965. Manaus: Missões Salesianas do Amazonas, 1965.

${ }^{12}$ Citado por J.V. CÉSAR, "Os índios e as Missões (VIII)", Atualização 139 / nº 140 (1981) 275 .
} 
missões que, igualmente, confirmaram as denúncias dos antropólogos de Barbados. Poder-se-ia apontar missões no Nordeste e de paróquias, no Sul do país, com sua pastoral de "bugres". Hoje, setores significativos da Igreja desenvolvem uma nova pastoral no espaço conflitivo entre as pulsões de vida (Eros) e destruição (Tanatos). O mal-estar na missão não se limita ao mal-estar com determinados setores eclesiais que negociam a paz (o suposto "bem-estar") com os poderes no interior dos sistemas ou ao mal-estar sobre o paternalismo das "boas intenções". Também a "missão libertadora", em outro nível, não escapa do mal-estar inerente à luta pela vida que exige "sacrifícios". Tanto um "Lunkenbein acomodado" como um "Lunkenbein sacrificado" causa mal-estar ${ }^{13}$. Ainda diante do cadáver do missionário e do índio na Missão Bororo, uma religiosa exclamou: "O que dirão agora os nossos benfeitores!"

Viver significa resistir à morte. As culturas são sempre culturas de resistência. E onde a missão se alia a esta resistência, exige abrir mão do aconchegante incesto eclesial, da menoridade auto-imposta (Kant) e da regressão prazerosa em benefício da exogamia, do caminho pelo deserto, da intervenção nos conflitos dos pobres, da presença nos confins do mundo, do cantar adulto em terra estranha. E quanto mais exogâmica a missão se torna, mais ela cria consciência de suas amarras endogâmicas, sistêmicas, incestuosas. No interior da Igreja, o ideal da exogamia missionária radical, Freud diria, o Eros, de uma ou outra maneira, fica sempre a meio caminho, por causa do Tanatos ${ }^{14}$. Eis o mal-estar na missão: a culpa pela incoerência pode-se transformar em apologia da mediocridade. O shalom, estacionado a meio caminho, pode-se tornar barbárie. A missão salvífica pode-se colocar a serviço da repressão. A missão exige um trabalho permanente de luto e de discernimento entre o desejo e os princípios de esperança e realidade.

\section{O Vaticano II}

A pressão do mundo moderno e a abertura do Concílico Vaticano II (1962-1965) tiveram um impacto sobre o relacionamento entre Igreja e povos indígenas. Nem sempre o tempo pós-conciliar coincide com um tempo pós-colonial. Continuam até hoje práticas e mentalidades baseadas mais na eclesiologia do Vaticano I do que na Lumen Gentium ou na Gaudium et Spes do Vaticano II.

${ }^{13}$ Cf. P. SUESS, "Rodolfo Lunkenbein, missionário e mártir", in: Idem, Cálice e cuia: Crônicas de pastoral e política indigenista, Petrópolis: Vozes, 1985, pp. 101109.

${ }^{14}$ S. FREUD, “O mal-estar...", Op. cit., pp. 102. 144ss. 
O espaço deste texto não permite a reconstrução histórica da relação entre povos indígenas e Igreja do passado. Mesmo assim é memória da paixão e ressurreição dos índios crucificados na história. Ao resgatar a memória dos condenados da terra da esfera do privado ou do proibido, um texto teológico é sempre também um texto político de reconstrução histórica e projeção utópica.

Mas os povos indígenas não são apenas ameaçados pelo simples esquecimento. Também a comemoração - a comemoração dos "500 anos" e o "Jubileu 2000" podem servir de exemplo - pode ser uma maneira sofisticada e cultural de esquecimento. O culturalmente correto e lembrado, as respectivas ondas de uma época, o padrão de santidade que serve, em correspondência com determinadas prioridades políticas e espirituais de um pontificado, para as canonizações, e o mainstream da ciência são afluentes do rio Lete, rio do esquecimento. $O$ que não foi publicado em inglês, de cinco anos para cá e em determinadas revistas de renome, recebe o carimbo do forget $i t^{15}$. Mártires e hereges, pobres e excluídos, outros e minorias que são a memória evangelicamente significativa de sua época, apontam para este imperativo de conveniência política do forget e delete.

A Igreja do Vaticano II se entende essencialmente missionária (cf. Ad Gentes 2 e 6, Lumen Gentium 1) e, ao contextualizar-se na Segunda Conferência Geral do Episcopado Latino-Americano de Medellín (1968), se tornaria explicitamente libertadora. A novidade do Concílio não estava na missionariedade como tal. Também a cristandade colonial hasteava a bandeira da missionariedade. Missão significava expansão territorial e incorporação jurídico-espiritual num espaço de plenitude salvífica, representado pela Igreja. A missão da cristandade é endogâmica, narcísica, eclesiocêntrica. Ela anunciava o Reino como uma extensão da Igreja.

O Vaticano II, com sua compreensão da "natureza missionária" da Igreja, transformou o olhar narcísico sobre si mesmo num olhar ad extra, sobre o mundo. A "essência missionária" do Vaticano II é exogâmica. Ao enamorar-se com as necessidades concretas da humanidade, e compreendendo a humanidade como humanidade mutilada que clama, sobretudo nos pobres, por libertação, a Igreja gera novos filhos e filhas, não resultados de uma relação endogâmica e incestuosa com suas deformações de infantilidade e subserviência, mas filhos e filhas adultos e livres.

${ }^{15}$ Cf. H. WEINRICH, Lete: Arte e crítica do esquecimento, Rio de Janeiro: Civilização Brasileira, 2001, pp. 293ss. 
Os pobres, na compreensão original do Concílio, não são apenas destinatários de uma opção, mas povo de Deus e sujeitos de uma nova evangelização ${ }^{16}$. A obra da redenção que Jesus Cristo realizou "na pobreza e na perseguição" (Lumen Gentium 8), a Igreja realiza "no seguimento do mesmo caminho" (ibid.). Só a Igreja dos pobres é capaz de realizar o projeto de Jesus, na pobreza e com os pobres. Nos pobres, "entre as perseguições do mundo e as consolações de Deus, a Igreja avança" (ibid.), se constitui povo de Deus e procura servir a Cristo.

Na práxis missionária junto aos povos indígenas dos anos pós-conciliares e pós-Medellín se percebeu, que a categoria "os pobres" precisava ser matizada, porque os povos indígenas não cabiam simplesmente como "os pobres dos mais pobres" nesta abordagem. No campo teológico-pastoral emergiu - primeiramente contra uma certa resistência dos "clássicos" da teologia da libertação, depois já com mais tolerância - a categoria do "outro" e da "alteridade" que tem como base material e espiritual, não a carência social, como a pobreza, mas a riqueza cultural dos sujeitos históricos, sempre ameaçada, mas também base de sua resistência histórica. A sobrevivência, resistência e continuidade históricas dos povos não têm por base a sua pobreza, mas seu projeto de vida, codificado em suas culturas. As culturas sempre são culturas de resistência, memórias da vida que venceu a morte, já que a vida só existe na resistência contra a morte.

"Pobreza" e "alteridade" não devem ser confundidas, nem separadas. Os outros-não-pobres representariam a classe média ou alta que construiu o seu estatuto de classe à custa dos pobres e os pobres-nãooutros seria a generalização de uma classe social, onde a diversidade de projetos de vida se tornaria um obstáculo e não uma contribuição para o bem comum e a libertação de todos. Para enfatizar essa vinculação se tem adotado o conceito "pobre-outro" ou, mesmo falando somente dos pobres, deve-se sempre subentender a sua diversidade cultural de projetos concretos. Por isso, as Conferências Gerais do Episcopado Latino-Americano de Puebla (1979) e Santo Domingo (1992) - apesar de todas as ambigüidades da última - acrescentaram à "opção pelos pobres" e à "Teologia de Libertação" também as questões da inculturação, não como alternativa mas como complemento necessário. A comunidade eclesial nunca separou estes dois mistérios. A eucaristia é a memória do "Verbo que se fez carne" e do "mistério pascal". O tempo solar de Natal aponta - no solstício da noite mais escura - para o processo da encarnação crescente. E na festa da lua cheia de Páscoa reflete a luz da libertação em Jesus Cristo sobre o mundo.

${ }^{16}$ Cf. M.-D. CHENU, “A Igreja dos pobres no Vaticano II”, Concilium (Br), 124 / $\mathrm{n}^{\circ} 4$ (1977) 61-66. 


\section{A hermenêutica do CIMI}

Por causa da questão da terra e da cultura, o chão das aldeias indígenas é um sismógrafo que registra os mínimos tremores macroestruturais, sejam estes de natureza política, econômica ou religiosa. O Vaticano II foi um destes acontecimentos macroestruturais, no interior da Igreja Católica, que repercutiu fortemente nos microcenários pastorais. Suas intenções foram lentamente contextualizadas na América Latina em inúmeras conferências e encontros. O Vaticano II e, em seguida, a Segunda Conferência Geral do Episcopado Latino-Americano (1968), em Medellín, ainda não tematizaram a "questão étnica". Trataram, sim, da "promoção da cultura" (Gaudium et Spes, 53-59), da "liberdade religiosa" (Dignitatis Humanae), do "valor salvífico" das religiões não-cristãs e do "diálogo" com os seguidores de outras religiões (Nostra Aetate, 2) ${ }^{17}$. "Diálogo" é a palavrachave do Vaticano II, como "libertação" se tornou a palavra-chave de Medellín. O Papa João XXIII, logo no início do Concílio, em sua Carta Encíclica sobre a Paz dos Povos, de 1963, qualificou a descolonização dos povos como um "sinal do tempo", que marca uma nova época.

A autocompreensão da Igreja pós-conciliar como "essencialmente missionária" permitiu um olhar mais concreto para o mundo e sua realidade. E essa Igreja missionária se compreende como povo de Deus em peregrinação, constituída pelos pobres que anseiam por sua libertação ${ }^{18}$. Na diversidade de suas culturas codificaram seus múltiplos projetos de vida. Através da inculturação nestes projetos, a comunidade missionária vive o seguimento de Jesus. Na inculturação, o mistério da encarnação se contextualiza - no tempo, no espaço e na convivência - como lugar teológico (Santo Domingo, 13). Este é o pano de fundo teológico da nova presença missionária junto aos povos indígenas que norteou o Conselho Indigenista Missionário (CIMI).

Até o início dos anos setenta, não existia uma pastoral indigenista de conjunto. A pastoral junto aos povos indígenas estava predominantemente sob a responsabilidade de Prelazias, entregues a ordens e congregações religiosas. Estas, em sua maioria, obedeceram antes a lógicas congregacionais que a prioridades pastorais. $\mathrm{Na}$ época da fundação do CIMI, em 1972, a sociedade brasileira e as Igrejas locais, em seu conjunto, não acreditavam na possibilidade de que os povos indígenas poderiam ter um futuro próprio, como povos e nações.

${ }^{17}$ Cf. para muitas questões ligadas ao desdobramento do Vaticano II na questão indígena: P. SUESS, A causa indígena na caminhada e proposta do CIMI: 19721989, Petrópolis: Vozes, 1989.

${ }_{18}$ Oportunamente, o padre J. Comblin chamou a atenção para a centralidade do conceito "Povo de Deus" no Vaticano II e sobre a centralidade dos pobres na Igreja "Povo de Deus". Cf. J. COMBLIN, O povo de Deus, São Paulo: Paulus, 2002. 
O documento-denúncia "Y-Juca-Pirama, o índio: aquele que deve morrer", foi - na mesma semana em que o Estatuto do Índio saía publicado no Diário Oficial - uma resposta de bispos e missionários ligados ao CIMI à política indigenista do governo. Ao lado da denúncia, figura o anúncio:

"Nada faremos em colaboração com aqueles que visam 'atrair', 'pacificar' e 'acalmar' os índios para favorecerem o avanço dos latifundiários e dos exploradores de minérios" (...). Nosso trabalho não será 'civilizar' os indios". (...) Chegou o momento de anunciar, na esperança, que, aquele que deveria morrer é aquele que deve viver" ${ }^{19}$.

Na década desenvolvimentista dos anos 70, seguida pela década perdida dos anos 80, as palavras "civilização", "progresso" e "desenvolvimento" exerceram ainda um certo fascínio e sua contestação era difícil. Geralmente, considerava-se a questão indígena uma "causa perdida". Parecia lógico que o caminho indicado para o futuro dos 90.000 (segundo dados do governo militar da época) ou 180.000 índios, segundo o recenseamento do CIMI de então, seria a integração nos padrões culturais e jurídicos da sociedade nacional e a assimilação étnica e religiosa. A perspectiva de integração na sociedade classista dispensaria a demarcação das terras dos índios e a sua proteção específica, a perspectiva da conversão dispensaria o diálogo inter-religioso e a inculturação. A integração, na chamada comunidade nacional, tornou-se a nova modalidade do etnocídio.

O povo Nambikuara foi vítima exemplar dessa política. A Funai, com seu presidente general Bandeira de Melo, retirou os índios de seu território que então seria atravessado pela BR-364. Retirados os índios, a Funai emitiu certidões negativas - atestados de que na região do vale do Guaporé não havia mais índios -, e a Superintendência para o Desenvolvimento da Amazônia (SUDAM) chamava, através de incentivos fiscais, as firmas colonizadoras. Mas os Nambikuara voltaram para seu habitat. Entre 1968 e 1979, o vale do Guaporé foi distribuído entre 22 firmas agropecuárias. No Natal de 1971, equipes da FAB e da FUNAI tiveram de resgatar de helicóptero os índios dispersos pelo vale. Os que escaparam da fome, tiveram sarampo. Na epidemia, morreu toda a população Nambikuara menor de 15 anos. O notícia da "Biafra brasileira" correu pelas manchetes dos jornais ${ }^{20}$.

Foi neste contexto, no contexto da construção da Transamazônica no governo do general Garrastazu Médici (1969-1974) e no contexto das

${ }^{19} \mathrm{O}$ documento "Y-Juca-Pirama. O índio: aquele que deve morrer", in: P. SUESS (org.), Em defesa, Op. cit., pp. 31-59; aqui pp. 52.53.58.

${ }^{20}$ Cf. V. CARELLI / M. SEVERIANO, Mão branca contra o povo cinza: Vamos matar este índio? São Paulo: Centro de Trabalho Indigenista, 1980, p. 12. 
denúncias de Barbados, que o CIMI iniciou seu trabalho com a "opção pelos povos indígenas", propondo a ruptura com o modelo desenvolvimentista em marcha e assumindo uma pastoral específica, integral e amplamente articulada. Uma solução justa da questão das terras dos povos indígenas exigiria mudanças profundas do modelo econômico e sócio-político vigente, com seus pilares de acumulação, autoritarismo e hegemonia política do economicamente mais forte. Obviamente, essa opção causou conflitos, não somente frente ao Estado, mas também no interior das Igrejas locais. Sobretudo, a pergunta para onde caminhariam os povos indígenas dividiu os espíritos. $\mathrm{O}$ CIMI começou com um ato de fé e esperança no futuro dos povos indígenas, num momento em que a política indigenista oficial e os setores articulados com o governo já deram a ordem de não ressuscitar o "paciente agonizante" na UTI do progresso. Os jornais falavam do "inevitável desaparecimento" dos povos indígenas. Mesmo indo a pique a bordo de um navio - réplica daquela nau de Cabral - com mastro quebrado, a classe dominante levanta já 500 anos as suas taças com cachaça e sangue, dando vivas à morte dos índios sem terra.

Cada um dos povos indígenas tem uma história traumática sobre o contato com a "comunidade nacional" a contar. A partir de 1987, milhares de garimpeiros invadiram as terras dos Yanomami, desorganizaram a economia indígena, desarticularam sua cultura e depredaram o meio ambiente, poluíram os rios com mercúrio e espalharam doenças e morte. Em dois anos, mais de 1500 Yanomami morreram. Aldeias inteiras desapareceram. Em agosto de 1987, o governo Sarney expulsou os missionários da Missão Catrimâni e as equipes médicas da Comissão pela Criação do Parque Yanomami (CCPY). Eram as testemunhas que podiam denunciar o genocídio em andamento. Em 1988, diariamente pousavam mais de 100 pequenos aviões em pistas clandestinas no território dos dez mil Yanomami.

Os povos indígenas são, até hoje, vítimas de "violência institucionalizada". O que os bispos latino-americanos afirmavam em Medellín para "os setores populares" valeu também para os povos indígenas: Paz e justiça para os povos indígenas "conquista-se por uma ação dinâmica de conscientização e organização"'21. Desde 1974 o CIMI facilitou encontros entre lideranças indígenas, não só no Brasil, mas em toda a Ameríndia, dos quais emergiram organizações autônomas com novos horizontes políticos e teológicos.

${ }^{21}$ CONSELHO EPISCOPAL LATINO-AMERICANO (CELAM). A Igreja na atual transformação da América Latina à luz do Concílio: Conclusões de Medellín, Petrópolis: Vozes, 1969 [5ª ed. 1973], Doc. II, "Paz", n. 18. 
A Missão Anchieta, em Diamantino (MT), foi o palco da primeira dessas assembléias de líderes indígenas. De 17 a 19 de abril de 1974, 16 chefes indígenas, representando os povos Apiaká, Kayabi, Tapirapé, Rikbaktsa, Irantxe, Paresi, Nambikuara, Xavante e Bororo, participaram do encontro. A luta contra a falsa emancipação, no governo Geisel, em 1978, fez surgir várias entidades em defesa da causa indígena, entre elas, a Associação de Apoio ao Índio (ANAÍ), Grupos de Estudo, Comissões Pró-Índio e o Centro de Trabalho Indigenista. Durante a Semana do Índio, de 1980, em Campo Grande (MS) surgiu a idéia de se criar uma "Irmandade Indígena" que veio a constituir-se sob a denominação União das Nações Indígenas (UNI). Quando a UNI procurava, através de sua coordenação em Brasília, representar os povos indígenas em âmbito nacional, ocorreu a desarticulação no interior do movimento indígena. Surgiram as questões da representatividade, da legitimidade, do distanciamento das bases, da desvinculação das próprias raízes culturais, das grandes estruturas e projetos e do estrelismo de lideranças.

Entre 1985 e 1988 surgiram várias organizações indígenas locais que produziram avanços significativos na Constituição Federal do Brasil de $1988^{22}$. Com a realização da Primeira Assembléia dos Povos Indígenas da Amazônia, em 1989, nasceu a Coordenação das Organizações Indígenas da Amazônia Brasileira (COIAB) que em pouco tempo se tornou uma referência para a política indigenista no Brasil e no exterior. Em conseqüência disso, surgiram vários atritos entre o movimento nacional, comandado pela UNI, e o movimento da Amazônia, coordenado pela COIAB. A partir de 1992, em âmbito nacional, a UNI cedeu lugar ao Conselho de Articulação dos Povos e Organizações Indígenas do Brasil (CAPOIB), na época mais ligado às bases e organizações regionais existentes. Em 1995, o CAPOIB realizou sua Primeira Assembléia Geral, já com a participação de 203 representantes de 76 povos e 40 organizações ${ }^{23}$. A Marcha e a Conferência dos Povos e Organizações Indígenas, realizada em abril de 2000, por ocasião dos "500 anos", contou com 3.600 índios de 140 povos $^{24}$. A intervenção repressiva de setores governistas neste evento sublinha a importância do movimento indígena massacrado na estrada que liga Porto Seguro a Santa Cruz Cabrália (BA).

Muitas lideranças indígenas no Brasil foram e continuam sendo assassinadas neste tempo pós-conciliar. Em 15 de julho de 1976, Simão

${ }^{22}$ Cf. ASSESSORIA JURÍDICA / CIMI (org.). Legislação indigenista brasileira, São Paulo: Loyola, 1989, pp. 15-18.

${ }^{23}$ Esta Assembléia realizou-se entre os dias 3 e 7 de abril de 1995, em Luziânia (GO). Cf. Porantim, XVII/173 (1995) 3-7; aqui p. 6.

${ }^{24}$ Cf. Movimento indígena, em CIMI, Outros 500: Construindo uma nova história, São Paulo: Salesiana, 2001, pp. 117-133. 
Bororo caiu ao lado de Rodolfo Lunkenbein, missionário salesiano, no pátio da aldeia de Meruri ${ }^{25}$. Em 26 de dezembro de 1979, Ângelo Pereira Xavier, cacique Pankararé, de Brejo do Burgo, no Norte da Bahia, foi assassinado. Em 29 de janeiro de 1980, Ângelo Kretã, líder Kaingang de Mangueirinha (PR), sofreu emboscada, depois de ter recebido ameaças de morte. O órgão tutor assumiu a explicação oficial do seu assassinato como "acidente automobilístico". Em 10 de julho de 1983, o índio Maxakali Alcides foi assassinado a golpes de facão, por José Rolinha, vaqueiro do fazendeiro Laurindo, quando regressava para sua aldeia, no Nordeste de Minas. No dia 25 de novembro de 1983, foi assassinado o líder indígena Guarani Marçal Tupã-i na farmácia da aldeia de Campestre (MS), onde trabalhava. Vinte dias antes, Marçal tinha recusado uma oferta de cinco milhões de cruzeiros, que lhe ofereceram para tentar convencer um grupo Kayová (subgrupo Guarani) da aldeia Piracuá, em Bela Vista, a abandonar a área onde vivia. Na madrugada do dia 20 de abril de 1997, Galdino Jesus dos Santos, Pataxó Hã-hã-háe, de Pau Brasil (BA), foi queimado vivo por quatro adolescentes de Brasília. Nas últimas duas décadas, 23 líderes Pataxó foram assassinados. Xicão Xukuru (Francisco de Assis Araújo), cacique do povo Xukuru de Ororubá e expressiva liderança indígena no Nordeste, foi assassinado com quatro tiros numa emboscada, praticada por pistoleiros, em 20 de maio de 1998.

Mas, os povos indígenas sobreviveram aos assassinatos e ao "progresso". Ao lado do Movimento dos Sem-Terra, os povos indígenas representam, hoje, uma das poucas forças organizadas que apontam para um novo conceito de desenvolvimento, de Estado e de Nação que não subordina as leis e decisões ao ditado da economia globalizada e dos monopólios privados. Um fato novo, na história do Brasil, são os chamados povos ressurgidos ${ }^{26}$. Por força de decretos imperiais e pela pressão de interesses econômicos da sociedade contemporânea, muitos povos e aldeamentos passaram a ser considerados extintos. $\mathrm{Na}$ maioria dos casos, os índios expulsos de suas terras viviam dispersos por várias regiões do Brasil, servindo como mão-de-obra barata para fazendeiros invasores de seus territórios. Passados décadas e/ou séculos, eles voltaram a aparecer, reivindicando seus territórios e seu nome próprio. A partir da sua memória histórica, forjada numa longa resistência, estes povos ressurgidos têm conseguido recuperar sua identidade e redesenhar seu projeto de vida. A Campanha da Fraternidade 2002, com o tema "Fraternidade e povos indígenas" e o lema "Por uma terra sem males", pode ser compreendida como gesto de assunção "afetiva" do rio pequeno da pastoral indigenista,

${ }^{25}$ Cf. P. SUESS, "Rodolfo Lunkenbein, missionário e mártir", Op. Cit., pp. 101-109.

${ }^{26}$ Cf. Povos ressurguidos, in: CIMI (org.), Outros 500, Op. cit., pp. 157-165. 
protagonizada pelo CIMI, no rio grande da CNBB e da Igreja do Bra$\mathrm{sil}^{27}$. Mas este gesto não elimina conflitos ideológicos entre os diferentes setores da Igreja e bases missionárias.

\section{A polêmica "essência missionária"}

A colonização não é somente um fato político e histórico. É também um estado de espírito que produz um clima cultural. Portanto, a colonização não terminou com a independência, como tampouco a "evangelização colonizadora" acabou com o Vaticano II. Atitudes coloniais permanecem presentes também na modernidade. $\mathrm{O}$ neoliberalismo, por exemplo, é um fenômeno da modernização capitalista impensável sem as conquistas da modernidade. Ao mesmo tempo, com sua hegemonia econômica e cultural, representa um tipo de neocolonialismo sem precedentes. Atitudes coloniais se reproduzem no campo religioso e cultural das nossas sociedades, a partir de leituras fundamentalistas e/ou neoliberais da realidade ou da própria revelação.

De uma maneira semelhante ao pensamento colonial na modernidade podemos compreender - o que nas vivencias cotidianas da fé não é raro - a presença de atitudes infantís na vida de um adulto. Neste contexto de práticas da fé "fora de época" - da época histórica ou faixa etária - que produz uma colonização como estado de espírito, pode-se compreender o desabafo de um leitor de um jornal paulistano que - através de novas práticas missionárias nas Igrejas - vê a sua fé profundamente abalada. No seu "desespero" enviou um e-mail ao secretariado do CIMI, de Brasília, mais ou menos nestes termos:

"No dia 14.01.02, em entrevista concedida ao jornalista Roldão Arruda, do O ESTADO DE S.PAULO, a Ir. Elizabeth Aracy Rondon Amarante, da Congregação do Sagrado Coração, missionária entre o povo Mynky no noroeste do Mato Grosso, assim responde a pergunta que lhe fez o repórter:

"- Ensina a sua religião a eles (aos índios)? Ela responde: "- Nunca.

Procuro incentivar a religião que possuem, pois tem uma força muito gran-

${ }^{27}$ Remeto aos diferentes textos que escrevi para divulgar a CF 2002: P. SUESS, "Por uma 'Terra sem Mal': Mito guarani e projeto de sororidade, in: J.O. BEOZZO (org.), Produzir a esperança: projetos de sociedade e utopia do reino: Curso de verão - XV, São Paulo: Paulus / Cesep, 2001, pp. 151-174. Idem, "Por uma 'Terra sem Mal': Mito guarani e Campanha da Fraternidade 2002, REB 244 (2001) 854-876. Idem, "Fraternidade e povos indígenas", Vida Pastoral, XLIII / n 223 (2002) 18-24. Idem, "Por uma terra sem males. Articulações da Vida Religiosa em torno da CF 2002", Convergência XXXVII / n 350 (2002) 80-91.

${ }^{28}$ E.A.R. AMARANTE, "Valores e desafios de uma sociedade indígena: o povo Mynky", in J.O. BEOZZO (org.), Produzir a esperança: projetos de sociedade e utopia do reino, São Paulo: Paulus / Cesep, 2001, pp. 99-117. 
de como fator de resistência cultural. Nos rituais religiosos, quando há oportunidade, partilho a minha fé, mas apenas como diálogo religioso ${ }^{28}$. A religiosidade deles é profunda, com espíritos bons e maus e a predominância de um grande espírito do bem. Falam com esses espíritos por meio de seus antepassados, os mortos" 29.

Depois o leitor pergunta, se essa é a orientação missionária dada pela Igreja, pela CNBB, pelo Santo Padre João Paulo II, e faz três observações:

"Jesus disse claramente: 'Ide, pois, fazei discípulos meus todos os povos, gentios; gregos, bretães, celtas, germanos, gauleses, etc. inclusive os índios mynky - batizando-os em nome do Pai e do Filho e do Espírito Santo, ensinando-os a observar tudo aquilo que vos mandei. E eis que estou convosco todos os dias, até o fim do mundo" (Mt. 28, 19).

- Para a Ir. Elizabeth todas as crenças e religiões são relativas, se igualam, todas são boas, não existe nenhuma única verdadeira.

- Se Pedro, Paulo, André, Tiago, João pensassem como a Ir. Elizabeth em procurar incentivar a religião que possuem, o cristianismo não existiria! Os primeiros missionários violentaram tradições seculares, não respeitaram a resistência cultural dos gregos, bretães, celtas, etc., mas obedeceram à ordem do Mestre, catequizando, ensinando o Credo, as verdades básicas do cristianismo. A resistência dos gentios foi tamanha que lhes custaram a própria vida; se tornaram mártires. Não temos porque duvidar da religiosidade profunda, da seriedade e devoção dos romanos e gregos pelos seus deuses: Zeus, Apolo, Afrodite, etc., nem dos germanos e viquingues que adoravam Odim e Tór. Como para nós, para eles, religião era coisa séria, não era uma brincadeira mitológica folclórica, embora hoje, para muitas pessoas possa parecer. Que dizer então de São Francisco Xavier que sozinho - com a força da sua fé no Espírito Santo converteu 350.000 japoneses ao cristianismo - sem sequer dominar aquela língua estranhíssima - violentou uma cultura milenar! Do Beato José de Anchieta que traduziu o catecismo do Concílio de Trento para a língua tupi e não respeitou a profunda religiosidade deles - dos índios - com espiritos bons e maus!

"A Ir. Elizabeth, continua o leitor, sem a menor dúvida tem os seus méritos, é uma idealista, é uma devotada à causa indianista, seguidora fiel de seu avô, o valoroso Marechal Rondon; voluntária colaboradora, não remunerada, do CIMI, mas que jamais poderá ser considerada uma missionária da palavra de Deus.

${ }^{29}$ O CIMI Brasília recebeu este e-mail no dia 7 de março de 2002. Foram corrigidos alguns erros e cortados alguns trechos. 
Pelo amor que os senhores têm a Deus: se eu não estiver em sintonia com a Igreja, com as intenções do Santo Padre João Paulo II; se eu estiver errado me corrijam, não permitam que eu permaneça no erro, não se omitam, senão serão coniventes com o meu erro, pois eu pretendo ser e morrer um fiel cristão, Católico Apostólico Romano."

Tais perguntas poder-se-ia considerar como expressões de um malestar profundo, proveniente de uma crise múltipla:

- crise tardia de uma prática religiosa colonial,

- crise gerada pela compreensão fundamentalista da Bíblia que nem científica, nem historicamente está de acordo com a realidade e os desafios de hoje,

- crise de fé que nunca se tornou adulta, portanto, de uma crise de práticas infantís da fé,

- de uma crise de identidade do "bom católico" que reduz o seguimento de Jesus à observância de costumes, regras e leis ${ }^{30}$.

Porém, essas perguntas do leitor desesperado emergem também, embora com outra roupagem, em setores eclesiásticos mais esclarecidos que não podem, sem mais nem menos, ser acusados de desconhecimento histórico ou de práticas infantis da fé.

Uma saída, hoje muito em moda, é a cobrança de "pensamento positivo". Por que o CIMI fala sempre das terras indígenas não demarcadas, da escravidão dos afro-americanos, da fraternidade negada? Por que não falar do "presente" da fé em Jesus Cristo? Brasil não é apenas a terra do pau brasil roubado, é também a "Terra da Santa Cruz", que deu certo. Essas perguntas são, muitas vezes, remendadas com questionamentos sobre a "evangelização explícita". Por que a Ir. Elisabeth não é uma "missionária da palavra de Deus"? Onde está a "evangelização explícita" na prática missionária do CIMI?

Atrás destes e outros questionamentos não se escondem necessariamente "inimigos dos índios", nem "adultos com uma fé infantil", nem "agentes do latifúndio". E quando um bispo zeloso afirma: "Eu amo os índios e odeio o CIMI", nós nos perguntamos: Por que nossa prática missionária é tão incompreendida e tão polêmica? Por que este mal-estar recíproco? Não se está, muitas vezes, acusando o carteiro pelo conteúdo da carta? Não falou o Concílio que "Deus pode, por caminhos d'Ele conhecidos, levar à fé os homens que, sem culpa própria, ignoram o Evangelho" (Ad Gentes, 7)?

${ }^{30}$ Cf. J. COMBLIN, Um novo amanhecer da Igreja? Petrópolis: Vozes, 2002, p. 60. 
Muitas discussões que deram grande seriedade às sessões do Concílio, hoje parecem ser esquecidas. Não seriam também os povos autóctones parceiros privilegiados de um diálogo religioso? Não interessa, também a eles, a liberdade religiosa, a libertação de todas as formas de colonialismo, o respeito a sua cultura e, afinal, à sua autodeterminação no campo político e religioso?

Quando depois da Missa dos 500 anos, dia 26 de abril 2000, o bispo local pediu desculpas ao secretário do Estado do Papa, o cardeal Ângelo Sodano, pelas palavras do Pataxó Matalawê, pediu desculpas pela realidade brasileira e pela consciência indígena ${ }^{31}$. A essência do Evangelho pode ser encontrada no "louvor" ao Senhor do salmista e na "discussão" com o Senhor de Jó, que representa a humanidade crucificada.

Se a religião dos povos indígenas, neste momento histórico, é um instrumento de defesa de sua vida, a missão não deve enfraquecer esta resistência atraves de conversões apressadas. "Apressadas" porque se converter, hoje, de uma religião indígena para o cristianismo não significa entrar numa tradição cultural e filosófica de mais de dois mil anos. O árduo caminho da inculturação, com as tentativas da "Teologia Índia", da "Igreja autóctone", das liturgias com o "culturalmente disponível", é a tentativa de trazer o cristianismo mais perto dos respectivos povos e encurtar o tempo e espaço entre a "versão final" do cristianismo, muitas vezes teórica, e das religiões indígenas concretamente vividas. O testemunho de Ir. Elisabeth, que não exclui a conversão do povo Mynky, nem insiste nesta conversão apressadamente como meta prioritária, porque prioritário é a vida em abundância, que é um dom de Deus, não é a verdadeira Palavra de Deus que se fez carne? Elisabeth Amarante e muitos outros missionários do CIMI não estariam exatamente fazendo o que o Vaticano II propõe: "com prudência e amor, através do diálogo e da colaboração com os seguidores de outras religiões, testemunhando sempre a fé e vida cristãs, [para que os Mynky] reconheçam, mantenham e desenvolvam os bens espirituais e morais, como também os valores sócio-culturais que entre eles se encontram" (Nostra Aetate, 2)? O "testemunho" também é "evangelização explícita". O testemunho não é "evangelização light". Falar explicitamente, muitas vezes, é mais fácil do que testemunhar.

Não devemos confundir o diálogo inter-religioso com o ecumenismo. No ecumenismo busca-se construir a Una Sancta, a verdadeira e única Igreja de Cristo. Ela é um projeto sempre em construção que se compreende como pars pro toto, como representante salvífica para todos,

${ }^{31}$ Discurso de Matalawê (Jerri Adriani dos Santos) com comentários: Porantim XXII / 225 (2000), p. 18. 
quer dizer, sem exclusão de ninguém, e, ao mesmo tempo, sem coincidir com a humanidade inteira.

No diálogo inter-religioso, na Ásia, por exemplo, e, de uma certa maneira, também junto aos povos indígenas, ninguém propõe a substituição das grandes e pequenas religiões por uma religião única, porque se admite, em níveis distintos, o valor salvífico delas. Senão, o Papa não poderia se encontrar com representantes de outras religiões, sem propor a todos eles a conversão ao cristianismo. Quem poderia, no encontro de João Paulo II com representantes de outras religiões, na Igreja de São Francisco, em Assis, na celebração e oração em comum, distinguir entre a "fé teologal" do Papa e a "crença própria das outras religiões" ${ }^{\prime \prime 2}$, como a Declaração Dominus Iesus faz?

Precisamos, sim, estar "sempre prontos para responder a todo aquele que nos pedir a razão da nossa esperança" e fazê-lo "com suavidade e respeito" (1Pd 3,15). E isso por dois motivos:

Primeiro, a prática missionária pós-conciliar - a Nova Evangelização - fez as pazes com as conquistas da modernidade que beneficiam os pobres e os outros, como a subjetividade, a participação, a autodeterminação, a solidariedade e a igualdade de direitos. $\mathrm{O}$ evangelho e modernidade não admitem discursos em si hegemônicos. Cada discurso tem aquela autoridade que lhe provém de sua racionalidade e do seu convencimento eclesial.

Segundo, as doutrinas da e na Igreja dependem também do consentimento dos pobres e dos outros. Elas só têm validade a partir do momento, quando são "aceitas" ("recebidas") pelo povo de Deus.

Ambos os motivos - a prática democrática na modernidade e a necessidade do convencimento e da assunção eclesial de um dogma, por exemplo, ou de uma nova prática -, configuram a direção de uma missionariedade ad intra, não como na cristandade, como ponto de partida, mas como ponto de chegada. O CIMI não tem apenas uma missão junto aos povos indígenas ou à sociedade nacional, mas também junto à comunidade eclesial. Ao mudar as práticas do encontro com o outro (ad extra) mudam também as explicações e fundamentações destas práticas no interior da Igreja.

Assim, estamos diante de duas tarefas que emergem do estar "sempre prontos para responder a todo aquele que nos pedir a razão da nossa esperança" e fazê-lo "com suavidade e respeito":

${ }^{32}$ CONGREGAÇÃO PARA A DOUTRINA DA FÉ, Declaração Dominus Iesus sobre a unicidade e universalidade salvífica de Jesus Cristo e da Igreja, Roma 2000, n. 7. Cf. sobre a infalibilidade do povo de Deus no ato da fé, na oração: G. THILS, L'infaillibilité du pueple chrétien 'in credendo', Paris / Louvain: Desclée de Brouwer / E. Warny, 1963. 
- aos povos indígenas precisamos explicar que não somos mais estes missionários coloniais, convictos dos benefícios de sua presença para os povos indígenas, sem perguntar aos próprios povos indígenas e sem admitir uma resposta discordante,

- e aos missionários e aos que têm responsabilidade na hierarquia eclesial precisamos explicar porque não somos mais estes missionários que, na incorporação do outro e na sua redução ao mesmo, criaram um "continente católico", não só estatisticamente satisfatório, mas também, sob certo aspecto, "bem sucedido" em suas tentativas de resignificação do universo indígena encontrado.

Mas como servir a dois senhores, sem pregar um evangelho morno que seria uma nova fonte para o mal-estar na missão?

O cristianismo tem, com a maioria das religiões, a fé num Criador do mundo e da humanidade em comum. Já com muito menos religiões, os cristãos partilham a revelação de Deus através de livros sagrados. Nenhuma religião, porém, foi tão longe, como a cristã, em afirmar que o próprio Deus se encarnou neste mundo para mostrar o caminho da vida, da verdade e da justiça. Sobre esta afirmação não existe a mínima possibilidade de "negociar" semelhanças ou identidades com outras religiões. Portanto, nenhuma religião pode, segundo a compreensão do cristianismo, recorrer a uma autoridade maior que o "Verbo encarnado". O cristianismo, segundo a sua compreensão de si mesmo, é a última instância em matéria de justiça, verdade e vida, sobretudo compreendendo a vida como "vida em abundância" que poderia ser só abundante na articulação entre "vida histórica" e "vida escatológica".

A "autoridade maior" do "Verbo encarnado" causou, historicamente, mais problemas que solucionou. Como fazer prevalecer essa "autoridade maior"?

Para organizar essa "autoridade maior" em função da vida plena, a própria Igreja recorreu - entre o Édito de Milão, de 313 (Constantino) e a Paz de Westphalia, que pôs fim à guerra dos trinta anos (16181648 ) - ao poder imperial. Ela reproduziu as estruturas imperiais como estruturas eclesiásticas no interior da religião do Estado. O Estado se subordinou, progressivamente, à administração da religião pela Igreja, "denominada católica, por ser universal" ${ }^{33}$. Essa "universalidade" ou "catolicidade" foi compreendida como "exclusividade".

Por vários motivos essa compreensão da verdade e da vida perdeu seu caráter hegemônico e universalmente reconhecido:

${ }^{33}$ S. AGOSTINHO, A verdadeira religião, São Paulo: Paulinas, 1987, p. 47 (cap. $7,12)$. 
- Com a secularização, a Igreja perdeu as "duas espadas", a "plenitude de poder", e se dissolveu o "plurissecular conúbio entre Céu e Terra, auctoritas pontifícia e potestas imperial" ${ }^{34}$.

- Com a proliferação de outras religiões no interior de um Estado moderno, pluralista e democrático, nenhuma religião pode contar com o privilégio de ser tratada como religião do Estado. A convivência de credos distintos faz parte do estado constitucional.

- Com o novo enfoque das teologias pós-conciliares das realidades terrestres, do trabalho, da matéria e do mundo ${ }^{35}$, das teologias contextuais, das teologias do Terceiro Sujeito ("Teologia Índia", por exemplo), das "leituras materialistas" da Bíblia e da compreensão da história como lugar teológico, irromperam novas perguntas na comunidade eclesial.

Qual é a relação entre a "autoridade maior do Verbo encarnado" e o contexto histórico, a estrutura eclesial, os pobres-outros, enquanto sujeitos, e povo de Deus e as outras religiões e denominações religiosas?

\section{Aprendizados e reorientações}

Custos e benefícios da presença missionária junto aos povos indígenas podem ser avaliados pelo espaço que soube criar para o reconhecimento e o protagonismo desses povos. Esta presença não é historicamente autônoma. Portanto, não pode ser inventariada separadamente do inter-relacionamento com outros atores e fatores de natureza política, econômica e sócio-cultural, que intervém nos projetos de vida dos diferentes povos. A rigor, é uma generalização indevida querer resumir num denominador comum uma "presença missionária" que se desdobra em inúmeros cenários pastorais, junto a 235 povos indígenas contemporâneos nossos, profundamente diferentes entre si, em sua cosmovisão e prática histórica e social.

Essa heterogeneidade vale também para a presença missionária. Além da Igreja Católica atuam outras trinta denominações religiosas e/ou Igrejas junto aos povos indígenas no Brasil ${ }^{36}$. O cenário das Irmãzinhas de Charles de Foucauld, junto aos Tapirapé (MT), é bastante diferente

${ }^{34}$ G. MARRAMAO, Céu e terra, São Paulo: UNESP, 1994, p. 21.

${ }^{35}$ Cf. G. THILS, Théologie des réalités terrestres: I. Prélude, II. Theologie de l'histoire, Louvain: Desclée de Brouwer, 1946/1949. M.-D. CHENU, Pour une théologie du travail, Paris: Seuil, 1955. Idem, Théologie de la matière, Paris: Cerf, 1968.

${ }^{36}$ Cf. P. SUESS, "Religiões dos povos indígenas" in: Guia para o diálogo interreligioso $=$ Estudos da CNBB, 52, São Paulo: Paulinas, 1987, pp. 67-78, 69s. 
do cenário da Missão Salesiana, junto aos Xavante (MT), ou daquele junto aos Waimiri-Atroari ${ }^{37}$. A redução desta complexidade ideológica, prática e histórico-cultural de ambas as partes - sociedades indígenas e sociedade/cenários não-indígenas - a eixos, paradigmas e imperativos, é o preço a pagar pela avaliação e projeção cabal de práticas teológicas interculturais.

A filosofia que norteia e legitima, hoje, a presença missionária mais esclarecida e, por um lado relativiza, por outro faz assumir o "malestar na missão", como condição humana, pode ser resumida nas seguintes teses: ${ }^{38}$

1. O olhar exógeno sobre as culturas impõe limites estruturais para sua observação. O nosso olhar transforma a realidade social. Ao lembrar o passado dos povos indígenas, ao respaldar a sua memória e interpretar seu projeto, sempre somos interventores na oralidade de projetos históricos em andamento. Oralidade exige presença. Essa presença da comunidade missionária - as tentativas de inculturação - ainda pode ser considerada extremamente precária.

2. O que está em jogo na avaliação de "custos" e "benefícios" da presença missionária não é a não-intervenção religiosa como tal ou a moratória missionária, mas seu caráter diaconal para a autodeterminação e o reconhecimento dos povos indígenas. Em nome de uma suposta autenticidade cultural, hoje, querer erradicar um cristianismo historicamente incorporado na vida de muitos povos indígenas seria uma atitude tão colonialista, como a implantação do cristianismo contra a vontade de um povo que vive sua própria religião.

3. O "início da história do Brasil" não coincide com a conquista do país ou com a formação do Estado brasileiro. As nacionalidades e as histórias dos chamados povos latino-americanos não podem ser contadas sem as histórias milenares dos povos indígenas. O cientista social trabalha com a hipótese de que a nacionalidade brasileira é, antes de ser um pressuposto, uma meta no plural.

4. Os povos indígenas chamam a atenção para a fragilidade do sistema parlamentar e para a parcialidade elitista de todo o sistema da democracia representativa. Frente à globalização do capital e do merca-

${ }^{37}$ Cf. E. SCHWADE, "Waimiri-Atroari: A história contemporânea de um povo na Amazônia", in: CEHILA, História da Igreja na Amazônia, Petrópolis: Vozes, 1992, pp. 366-392.

${ }_{38}$ Estes "Aprendizados" representam a continuação da reflexão iniciada com "A história dos Outros escrita por nós. Apontamentos para uma autocrítica da historiografia do cristianismo", in: P. SUESS. Evangelizar a partir dos projetos históricos dos Outros. Ensaios de missiologia, São Paulo: Paulus, 1995, pp. 61-90. 
do protagonizado por agentes locais, as democracias administradas no interior do Estado nacional se tornam cada vez menos capazes de garantir o bem comum. Sobretudo, em países onde os povos indígenas representam "minorias", a operacionalidade histórica de seu projeto depende de alianças com a sociedade civil e de articulações amplas.

5. Junto aos excluídos e marginalizados, os povos indígenas fazem parte do Terceiro Sujeito que emerge ao lado do primeiro sujeito, a burguesia, e do segundo sujeito, representado pelo operariado e campesinato. O Terceiro Sujeito não configura uma alternativa à modernidade, mas seu resgate e complementação. Os povos indígenas não são anti, extra ou pré-modernos; representam a cobrança das promessas da modernidade: a autonomia, a autodeterminação, a subjetividade, a racionalidade vivencial, a articulação da diversidade cultural com a solidariedade social, o direito a visões do mundo diferentes e o reconhecimento dos direitos humanos universais.

6. Os povos indígenas não estão de passagem neste Continente. $\mathrm{O}$ "neolítico indígena" de hoje tem estatuto histórico próprio. O mito e a história, a magia e a ciência são visões complementares do mundo. Representam soluções específicas e limitadas de cada mundo. "Entre nós", escreve Lévi-Strauss, "os conhecimentos positivos transbordam de tal forma os poderes da imaginação que esta, incapaz de compreender o mundo cuja existência lhe é revelada, tem como único recurso voltar-se para o mito"'39. Os fenômenos da física quântica nos são tão estranhos como as mais fantásticas invenções míticas. Graças a Freud, o mito de Édipo se tornou um explicador da condição humana na modernidade. "Do modo mais inesperado, é o diálogo com a ciência que torna o pensamento mítico novamente atual" ${ }^{\prime 4}$. A ordem diferente das coisas do mundo indígena frente ao "mundo moderno" pode ser ao mesmo tempo uma ordem complementar, alternativa e explicativa para a humanidade.

7. Ao resgatar criticamente a memória histórica dos povos indígenas do esquecimento e das explicações oficiais, a reflexão teológico-pastoral fortalece suas lutas atuais. Pela amnésia estrutural das respectivas sociedades nacionais e as distorções ideológicas dos vencedores que fazem confundir chavões com palavras-chaves ("laboratório racial", "comunidade nacional", "integração"), o tempo que passou e o que há de vir igualmente estão ameaçados. A tradição e o futuro estão igualmente ameaçados pelo esquecimento como pela corrupção. Nenhum passado "glorioso" garante - "na fé ou na marra" - fatalmente o futuro do pro-

${ }^{39}$ C. LÉVI-STRAUSS, História de lince, São Paulo: Companhia das Letras, 1993, p. 10.

${ }^{40}$ Ibidem. 12. 
jeto histórico de um povo ou grupo social. Basta lembrar que além dos 64 povos ressurgidos nos últimos 30 anos, no século XX mais de 80 povos indígenas foram extintos por doenças e violência física.

8. Os povos indígenas não são "objeto" de pesquisas, mas sujeitos de uma memória a ser resgatada. "Conhecimento" e "compreensão", no paradigma ocidental que cunhou o "ideal" da objetividade, são sempre procedimentos de identificação, de inclusão/exclusão e coisificação. Por isso, não se deve confundir "solidariedade" e "amor pela causa" com "identificação". A identificação do não-índio com o índio seria o revés da integração do índio na sociedade não-indígena.

9. O reconhecimento do Outro só é possível se admitimos que realmente não o conhecemos, já que o conhecimento é tendencialmente uma forma de integração no conhecido e no próprio. O reconhecimento do Outro é sempre o reconhecimento de sua alteridade. Este reconhecimento acontece em três níveis diferentes, através do direito, da estima e do amor, assim como também o não-reconhecimento pode ser registrado em nível de injustiça, desprezo e ódio. Pelo direito postulamos uma igualdade, portanto, um reconhecimento universal para todos. A estima está vinculada a valores e prestígios sócioculturais partilhados num determinado contexto e, muitas vezes, expressos em gestos simbólicos (títulos, cerimônias, vestidos). A estima e, mais ainda, o amor fogem da obrigatoriedade do direito. Com o direito, a estima e, de certa maneira, também a solidariedade estamos na esfera da reciprocidade. $O$ amor nos introduz no campo da gratuidade. $\mathrm{O}$ amor é a compensação unilateral de uma desigualdade não contemplada pela lei. Portanto, não pode ser cobrado nos tribunais, nem exigido de todos. A coerência da presença missionária deve ser avaliada, sobretudo, frente a essa gratuidade.

10. Os setores solidários não são porta-vozes das vítimas. Eles defendem os povos indígenas por uma opção, não por um mandato indígena ou por um conhecimento melhor. A solidariedade interrompe perspectivas evolucionistas ou idealistas que confundem progressos tecnológicos com avanços civilizatórios. O evolucionismo hierarquiza as culturas. As vítimas da história desmentem o evolucionismo social. As classes subalternas sabem que sua vida e sua história podem ser interrompidas a qualquer instante. A regressão à barbárie, que interrompe qualquer "processo civilizatório", não só é possível, mas representa um fato cotidiano. A cada instante histórico e atrás de cada ato heróico, nos confrontamos também com a regressão à barbárie. $\mathrm{O}$ presente "civilizatório" das respectivas sociedades nacionais não representa o futuro dos povos indígenas. $\mathrm{O}$ sofrimento e a alteridade nunca se compreendem plenamente. $\mathrm{O}$ genocídio dos povos indígenas não pode ser explicado, mas deve ser lembrado. 


\section{A ruptura}

Na Igreja, a missão representa a "exogamia", a proibição do "incesto eclesiocêntrico" pela "ordem do Pai". "Como o Pai me enviou, assim também eu vos envio a vós" (Jo 20,21). A "ordem missionária" é "ordem do Pai" que se torna "natureza missionária" (Ad Gentes, 2) pelo exercício num determinado contexto cultural e histórico. A história nos mostra que a interiorização da "ordem do Pai" que se tornou "natureza", não está isento do mal-estar causado pelas interferências do super-ego cultural, nem do desejo de compensações do calor do lar perdido com o calor da guerra santa e o poder. Mas, também existe, nas Igrejas, o mal-estar por ter ficado aquém da "ordem do Pai", por ter deixado a humanidade nas mãos do "príncipe deste mundo". O espiritualismo, o fundamentalismo e o narcisismo são modalidades regressivas e infantis de resistência contra a "ordem do Pai". A "ordem do Pai" é "convite ao testemunho", "com suavidade e respeito" (1Pd 3,15). Desautoriza o autoritarismo da sempre "penúltima palavra" humana que se impõe como se fosse a última.

Mais de duas décadas após a sua primeira declaração, o Grupo de Barbados apontou para a redução do "mal-estar na missão". Confirmou as mudanças ocorridas na ação pastoral, quando declara: "Reconhecemos a transformação ocorrida na corrente progressista da Igreja Católica que, nos últimos 20 anos, tem tentado reformular a prática eclesiástica com base no respeito às religiões indígenas. Todavia, setores majoritários desta instituição continuam exercendo um papel hegemônico que atenta contra os valores e as culturas indígenas" ${ }^{\prime 41}$. Como sair do círculo de giz do mal-estar na missão que é um malestar inerente à civilização ocidental?

O novo paradigma da pastoral indigenista está marcado por uma presença discreta, dialogal, testemunhal e profética, direcionada ao reconhecimento e protagonismo dos povos indígenas. E este paradigma não está em contradição com a "evangelização explícita". Aponta apenas para os meios que são, muitas vezes, a primeira mensagem. As "boas maneiras" e a solidariedade da comunidade missionária ensinam mais que seus discursos decorados ou shows bem ensaiados. $\mathrm{Na}$ cultura dos eventos e da visibilidade, o essencial continua invisível. No distanciamento da cultura hegemônica, na contra-cultura do projeto de Jesus que se encarnou neste mundo, sem ser deste mundo, está a possibilidade de mostrar que o "mal-estar na missão" não é natural ou fatal. É cultural, portanto, historicamente produzido. O empenho missionário na salvação dos povos não está na contramão da felicidade própria ou alheia. O próprio Freud, em Mal-estar na civilização, ad-

${ }^{41}$ Declaração de Barbados III: Articulação da diversidade, Porantim, 16 / n 164 (1994) 8s, aqui p. 9. 
mite que "uma pequena minoria de pessoas acha-se capacitada, por sua constituição, a encontrar felicidade no caminho do amor. (...) Essas pessoas se tornam independentes da aquiescência de seu objeto, deslocando o que mais valorizam do ser amado para o amar; protegem-se contra a perda do objeto, voltando seu amor, não para objetos isolados, mas para todos os homens (...). Talvez São Francisco de Assis tenha sido quem mais longe foi na utilização do amor para beneficiar um sentimento interno de felicidade ${ }^{\prime 42}$.

O evangelho aponta para práticas que desmontam a autodestrutividade e o "mal-estar na missão". São práticas contra-culturais num caminho pelo qual passa o projeto de Deus:

- A gratuidade radical da missão aponta para a possibilidade de rupturas sistêmicas e para o trabalho de luto como perdão e conversão.

- Um fruto da gratuidade será uma nova simplicidade material e doutrinal que pode ser compreendida como pressuposto da missão itinerante que testemunha a "leveza do ser". Ser "caminho" entre a conformação a este mundo e o fechamento num mundo próprio - leva ao encontro com Jesus crucificado e ressuscitado na caminhada dos crucificados na história. Simplicidade e itinerância apontam para a possibilidade do encontro com o outro.

- A Igreja, Povo de Deus, dispensa definitivamente a imagem, a simbologia, a atitude e a suntuosidade da "sociedade perfeita". Ela assume a sua ambivalência de "casta meretriz" junto aos pobres, povo de Deus constituído por "santos e pecadores". Os pobres perdoam todos os pecados da Igreja, menos a arrogância e o muro que os exclui. A presença dos pobres na casa de Deus é o indicador mais claro da acessibilidade da Igreja.

Gratuidade, simplicidade, itinerância e acessibilidade apontam para a possibilidade de romper com o fatalismo do "mal-estar na missão". Mas, a missão que é encontro, presença e discurso, é ao mesmo tempo encontro, presença e discurso de pessoas com uma pertença institucional de classe, nação e cultura. A missão nunca escapa totalmente do envolvimento em conflitos de interesses e relações de poder. Continua válida a tipologia do Documento Final do "Primeiro Encontro Pan-Amazônico de Pastoral Indigenista"43, de 1977, que destacava com um certo realismo a coexistência de três linhas diferentes de trabalho missionário: a tradicional doutrinadora e sacramentalista, a

\footnotetext{
${ }^{42}$ S. FREUD, $O$ mal-estar, Op. cit., p. 122.

${ }^{43} \mathrm{O}$ texto integral do Documento Final deste encontro que se realizou de 20 a 25 de junho de 1977, em Manaus, in: P. SUESS (org.). Em defesa, Op. cit., pp. 67-72.
} 
desenvolvimentista-paternalista e a encarnacionista-libertadora. Essas três práticas coexistem ainda hoje. Por isso, a missão Ad Gentes se dirige também ao interior da Igreja, com "suavidade e respeito". Os setores eclesiais, articulados com o movimento popular e indígena e com os projetos dos "pequenos", precisam, também no interior da Igreja, assumir o combate institucional pelo projeto de Jesus.

O projeto de Deus revelado aos "pequenos" fez Jesus exultar de alegria $($ Lc 10,21) e a Boa-Nova anunciada aos pobres "provoca os aleluias da Igreja" ${ }^{44}$. A aliança com os pequenos, a assunção da ambivalência como filtro contra qualquer prepotência, a gratuidade da vida vivida como uma grande ação de graças apontam para o projeto contracultural de Jesus que faz os muros do templo cair, rasga a cortina do mal-estar na missão e revela o anti-projeto em curso como gigante com pés de barro. Ao empenhar-se diariamente na defesa do reconhecimento e do protagonismo dos povos indígenas, nas lutas pelo território e na costura de alianças de solidariedade a comunidade missionária resgata, não os povos indígenas, mas a credibilidade de suas próprias Igrejas e recupera o seu bem-estar com a vida.

Paulo Suess nasceu em Colônia (Alemanha), em 1938, e estudou nas Universidades de Munique, Lovaina e Münster, onde se doutorou em Teologia Fundamental. Trabalhou na Amazônia e, a partir de 1979, exerceu o cargo de Secretário Geral do Conselho Indigenista Missionário (CIMI). Atualmente é coordenador do Departamento de Pós-Graduação em Missiologia, na Pontifícia Faculdade Nossa Senhora da Assunção, São Paulo, assessor teológico do CIMI e vice-presidente da Associação Internacional de Missiologia (IAMS). Entre suas publicações: Catolicismo Popular no Brasil São Paulo: Loyola, 1979, A Causa Indígena na Caminhada e Proposta do CIMI: 1972-1989, Petrópolis: Vozes, 1989, A Conquista Espiritual da América Espanhola Petrópolis: Vozes 1992 , Evangelizar a partir dos Projetos Históricos dos Outros, São Paulo: Paulus 1995.

Endereço: Caixa Postal 46-023 04046-970 São Paulo/SP

E-mail: suess@uol.com.br

${ }^{44}$ PAULO VI, Exortação apostólica sobre a alegria cristã (Gaudete in Domino), São Paulo: Paulinas, 1975, Conclusão, p. 51. 